\title{
Modeling of CFRP strengthened RC beams using the SNSM technique, proposed as an alternative to NSM and EBR techniques
}

\author{
Boulebd Adel, Ferhoune Noureddine \\ Department of Civil Engineering, Larbi Ben M'Hidi University, Oum el Bouaghi, Algerie \\ boulebdadel@botmail.fr,ferboune.noureddin@gmail.com
}

Boukhezar Mohcene

L.M.S.S., University of Constantine, Department of Civil Engineering, Larbi Ben M'Hidi University, Oum el Bouaghi, Algerie mohcene.boukhezar@gmail.com

Habib Abdelhak Mesbah

DSc., L.G.C.G.M., INSA of Rennes, University of Rennes 1, France

habib-abdelhak.mesbab@univ-rennes1.fr

\begin{abstract}
In this paper, an analytical and numerical study in finite element by the ABAQUS software was conducted. The goal of this work is to study the bending behaviour of reinforced concrete beams strengthened with the side near surface mounted technique. This technique is proposed as an alternative to overcome the unpredictable failure mode by the strengthening detachment resulting from the external bonded strengthening technique. Also, to avoid the failure mode by separation of the concrete cover ensuing from the near surface mounted technique. Moreover, a comparison between the behaviour of the three techniques, the effect of the quantity of strengthening as well as a validation of the results with the literature were presented. The results of this study show that numerical and analytical models can be used to predict the behaviour of reinforced concrete beams strengthened according to the three techniques. In addition, a clear improvement of the strengthened beams bending capacity is noticed. Lastly, the side near surface mounted technique preserves the ductility of the reinforced concrete beams modeled and therefore provides a better failure mode.
\end{abstract}

KEYwORDS. CFRP; SNSM; NSM; EBR; Failure mode.

\section{OPEN ACCESS}

Citation: Boulebd, A., Noureddine, F., Mohcene, B., Mesbah, H. A., Modeling of CFRP strengthened RC beams using the SNSM technique, proposed as an alternative to NSM and EBR techniques, Frattura ed Integrità Strutturale, 54 (2020) 21-35.

Received: 19.04 .2020

Accepted: 29.06.2020

Published: 01.10.2020

Copyright: (C) 2020 This is an open access article under the terms of the CC-BY 4.0, which permits unrestricted use, distribution, and reproduction in any medium, provided the original author and source are credited. 


\section{INTRODUCTION}

$\mathrm{I}$ $\mathrm{n}$ the last years, the fibre-reinforced polymer (FRP) has emerged as the material of choice for structural strengthening, due to its strengthening efficiency and light weight. Firstly, FRP was applied for the strengthening of the reinforced concrete (RC) beams according to the external bonded reinforced (EBR) technique. This technique is characterized by an easy implementation process [1] and a good strengthening efficiency [2, 3]. The EBR technique involves bonding FRP fabrics or laminates to the lower part of the RC beams using an epoxy resin. However, the disadvantage of this technique is the unpredictable failure and premature FRP debonding [4-7]. To overcome the failure mode of EBR techniques, the near surface mounted (NSM) technique was proposed [8-10]. It differs from the previous one by anchoring bars or rods in grooves recessed in the tensioned part of the RC beams, then filled using an epoxy resin. Indeed, this technique has overcome the disadvantages of the EBR technique. The NSM FRP strengthened beams have shown a better resistance and a better ductility. However, it must be noted that the failure mode by separation of the concrete covering is the disadvantage of this technique [11-16]. Thus, the side near surface mounted (SNSM) technique has been proposed as an alternative approach for strengthening RC beams to overcome the limitations of EBR and NSM techniques. The SNSM implementation process is similar to that of the NSM, except for the FRP strengthening, which is inserted in the lateral sides of the beam instead of the bottom part.

Several researchers, such as Al-Mahmoud F et al [17], Bilotta et al [11] and Sharaky et al [12], have studied the behaviour of the NSM technique. Their experimental investigations have shown a significant increase in the bending capacity of RC beams. These studies have also proved that the most frequent failure mode for the NSM technique is failure by separation of the concrete covering.

On the other hand, Hosen et al [18] studied the SNSM technique as an alternative to the NSM one. In their experimental investigation a significant improvement of $100 \%$ in bending capacity and $138 \%$ in load capacity were observed. In a second experimental and analytical study of Hosen et al [19], the results also showed that the SNSM strengthening technique significantly increases the first cracking capacities by $153 \%$, the yield by $108 \%$ and the extreme load by $147 \%$ compared to the control RC beam.

\section{RESEARCH SIGNIFICANCE}

7 his study has shown the efficiency of the analytical and 3D numerical models that have the ability to predict the behaviour of carbon fibre reinforced polymer (CFRP) strengthened RC beams using the three techniques SNSM, NSM and EBR with an accuracy of up to $97 \%$. In this study, it was clearly demonstrated that the SNSM technique overcame the disadvantages of the other two techniques. This includes: the debonding failure mode of the strengthening for the EBR; the failure by the separation covering of the concrete of the NSM. This achieved a preserved ductility at $72.7 \%$, a better mode of failure by the crushing of the compressed part of the concrete and a strengthening efficiency of $81.7 \%$. It is also noticeable that increasing the amount of strengthening increases the flexural capacity and rigidity of the RC beams strengthened using all the three techniques. This, along with a small advantage for the NSM technique.

For this purpose, this study is considered as a contribution to a better understanding of the behaviour of the SNSM technique, as there are few studies on this technique. Indeed, in the earlier studies on the SNSM technique, the majority of the beams studied have been tested using only the SNSM technique. However, our study aims to compare this technique with the other strengthening techniques NSM and EBR.

\section{NUMERICAL STUDY}

$\mathrm{T}$ he study includes a 3D finite element model implemented within the ABAQUS calculation software. This software was chosen because of its precision when it comes to modelling strengthened RC beams [20,21]. Seven RC beams have been subjected to four-point bending. We have chosen the four-point bending test for this numerical simulation to avoid shear failure. The load is modelled as a force reaction to a displacement imposed at two reference points coupled to the load application surface. The dimensions of RC beams were as follows: $2300 \mathrm{~mm}$ long, a rectangular crosssection of $125 \mathrm{~mm}$ wide and $250 \mathrm{~mm}$ high, with a span between supports of $2000 \mathrm{~mm}$. The reinforcement of the RC beams is composed of a steel of high adherence with $2 \mathrm{HA} 12$ in tensile and $2 \mathrm{HA} 10$ in compression. In order to avoid shear failure, a smooth-framed transverse reinforcement of $6 \mathrm{~mm}$ spaced $50 \mathrm{~mm}$ apart was placed along the RC beam. The seven RC beams were reinforced according to Fig. 1 and Tab. 1, with CFRP rods $10 \mathrm{~mm}$ and $12 \mathrm{~mm}$ in diameter, and a CFRP 
plate $2 \times 70 \mathrm{~mm}$ and $3 \times 70 \mathrm{~mm}$ in order to have a very narrow reinforcement sections. All strengthening elements have a length of $1900 \mathrm{~mm}$.

\begin{tabular}{ccc}
\hline$N^{\circ}$ & DESIGNATION & ID \\
01 & Referencing RC beam & REF \\
02 & Strengthened RC beam using the EBR technique with a 2x70 mm CFRP lamellae & EBR-10 \\
03 & Strengthened RC beam using the EBR technique with a 3x70 mm CFRP lamellae & EBR-12 \\
04 & Strengthened RC beam using the SNSM technique with $10 \mathrm{~mm}$ diameter CFRP rods & SNSM-10 \\
05 & Strengthened RC beam using the SNSM technique with $12 \mathrm{~mm}$ diameter CFRP rods & SNSM-12 \\
06 & Strengthened RC beam using the NSM technique with $10 \mathrm{~mm}$ diameter CFRP rods & NSM-10 \\
07 & Strengthened RC beam using the NSM technique with $12 \mathrm{~mm}$ diameter CFRP rods & NSM-12 \\
\hline
\end{tabular}

Table 1: Details of the RC beams modeled.

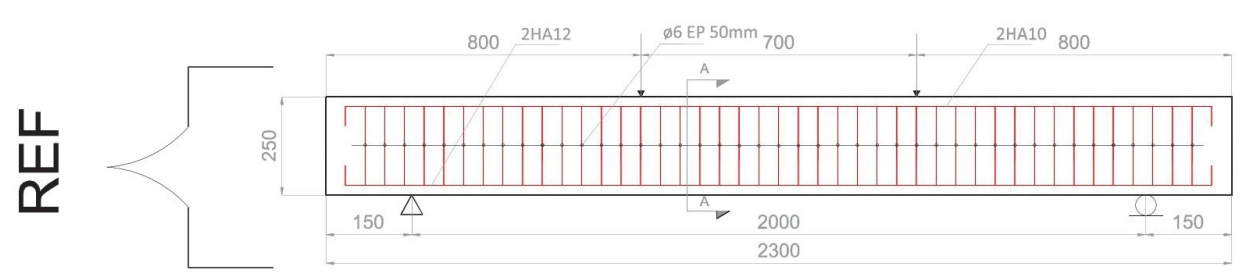

Referencing RC beam

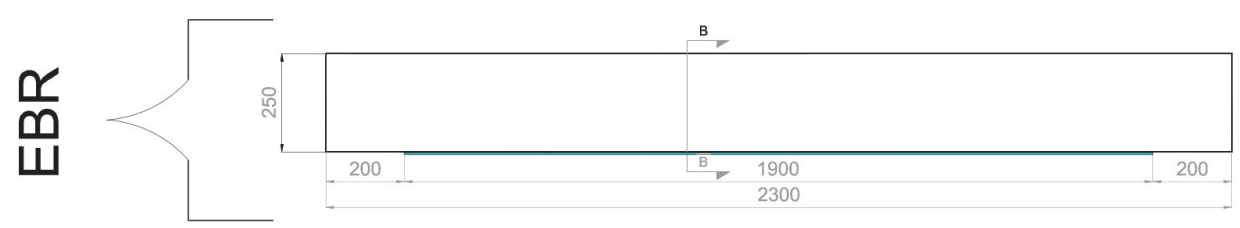

Strengthened RC beam using EBR technique
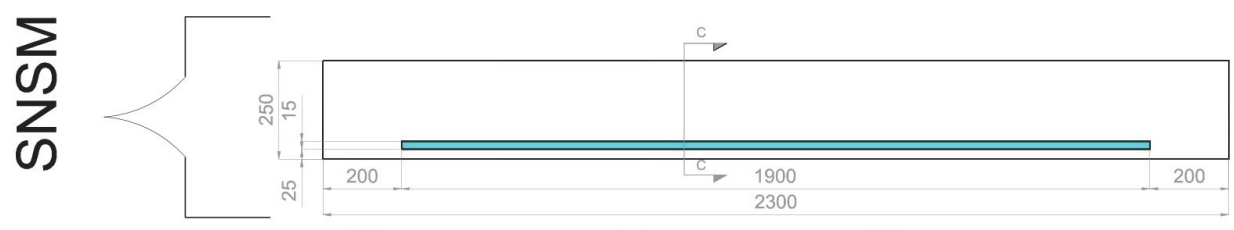

Strengthened RC beam using SNSM technique

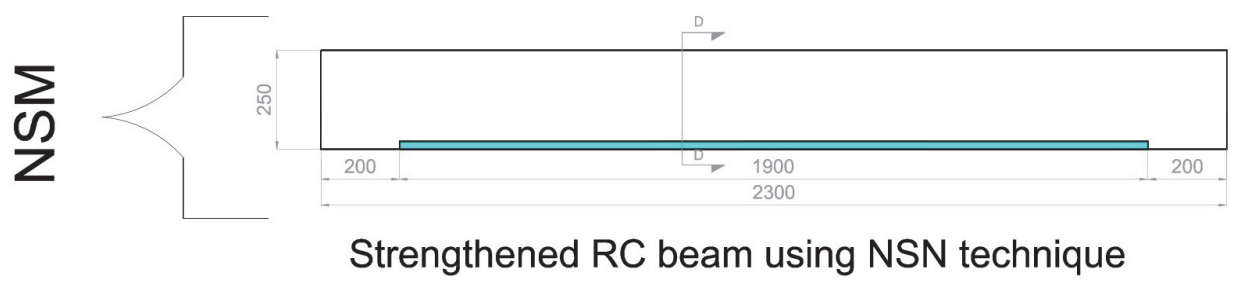

Figure 1: Configuration of the RC beams modeled.
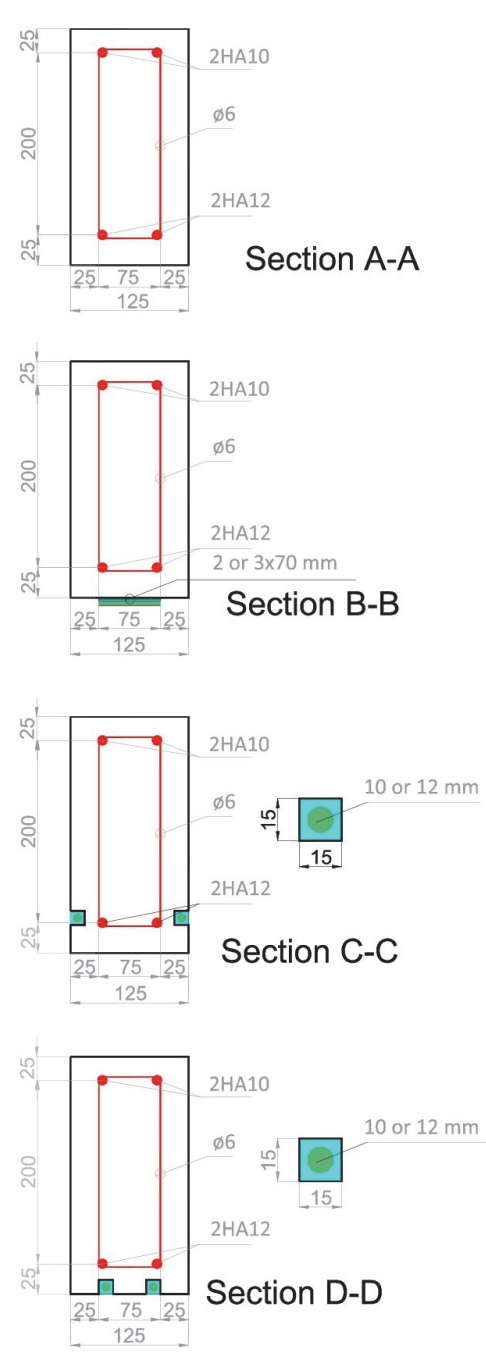

The strengthening mesh is type S4R5: a thin four node double curved shell, reduced integration, using five degrees of freedom per node. For the steel, the mesh is type T3D2: a 3-dimensional linear beam with two nodes. While for the beam, it is type C3D8R: a linear brick with eight nodes, reduced integration. However, the reinforcement zones have had a more refined mesh, which was necessary to converge. The total number of elements for the reference beam is 5064 with 17672 nodes, while for the reinforced beams the average number of elements is 9986 with 50887 nodes. 


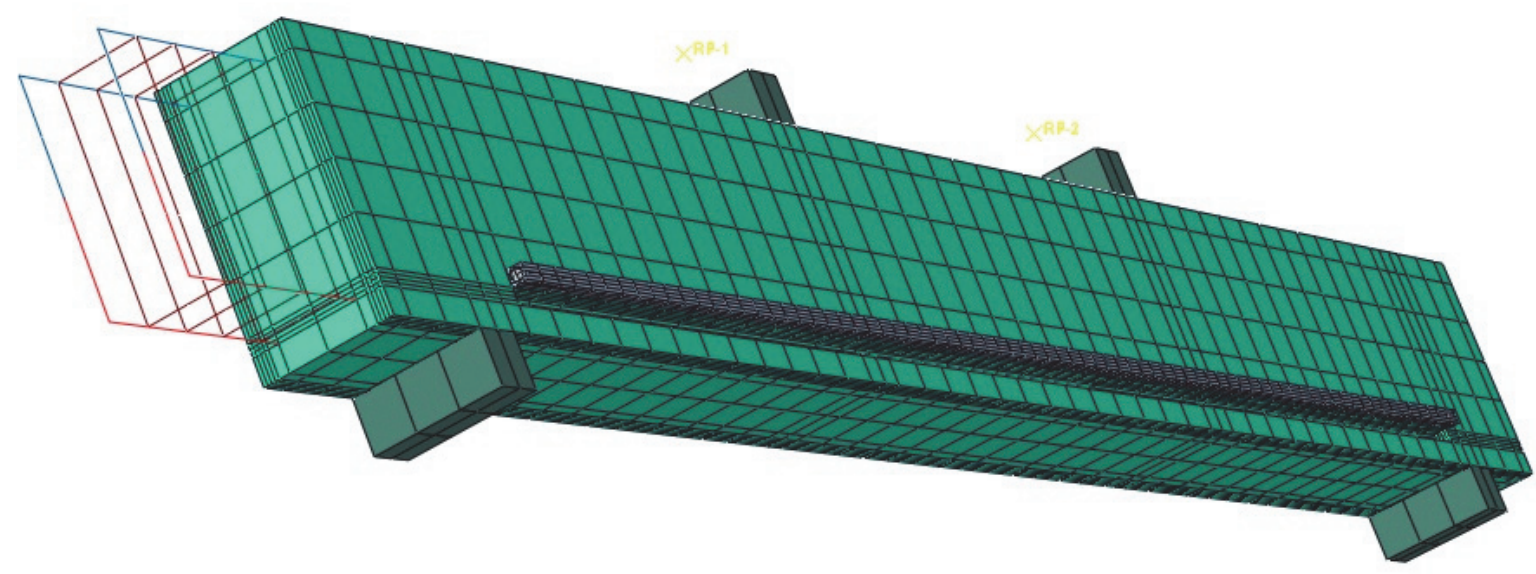

Figure 2: Mesh of the beams modeled.

\section{Material properties}

The concrete has been modelled as a solid element with 48.4 MPa compressive strength and 3.6 MPa tensile strength. The behavior law used is the concrete damaged plasticity (CDP) model that is a criterion reproducing a behaviour very close to the one of the concrete.

\begin{tabular}{cc}
\hline Parameters & Values \\
Dilation-angle & $36^{\circ}$ \\
Eccentricity & 0.1 \\
$\sigma_{\mathrm{B} 0} / \sigma_{\mathrm{C} 0}$ & 1.16 \\
$\mathrm{~K}$ & 0.667 \\
Viscosity & 0 \\
\hline
\end{tabular}

Table 2: Summary of the CDP model parameters [31],[32].

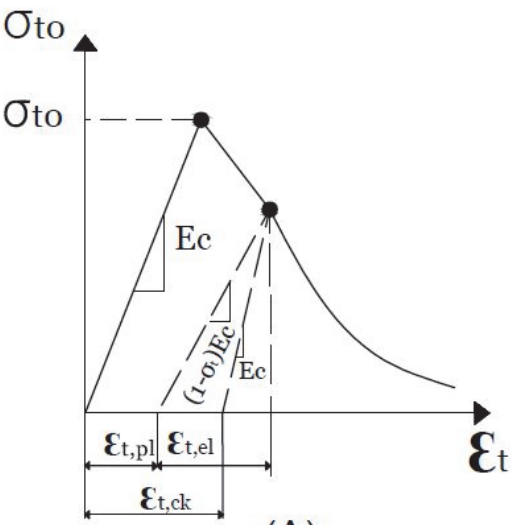

(A)

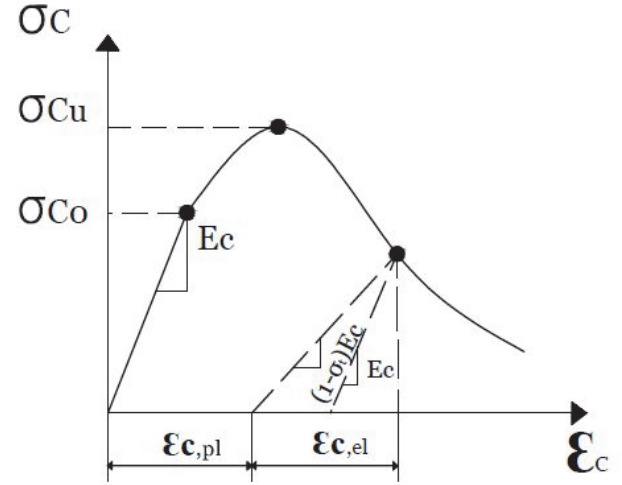

(B)

Figure 3: The concrete behavior law (A) tensile (B) compressive.

In order to model the steel reinforcement behavior, a firm wire rope element integrated into the concrete was used. A bilinear elasto-plastic behaviour law was used (Fig. 4(A)) with a density of $7850 \mathrm{~kg} / \mathrm{m} 3$, a modulus of elasticity $E_{s}=200 \mathrm{GPa}$, a coefficient $\mathrm{v}=0.3$, and a yield strength of $550 \mathrm{MPa}$ for the tension and compression and $300 \mathrm{MPa}$ for the transverse frame. The strengthening of the NSM and SNSM techniques is modelled according to a linear model as a solid element embedded in another solid element, which is resin with a concrete/resin and resin/strengthening interfaces of the cohesive type. The strengthening of the EBR technique is modelled as a sole element bonded by a cohesive interaction to the concrete. The 
CFRP has an elastic modulus $E_{f}=165 \mathrm{GPa}$ and a tensile strength of $3100 \mathrm{MPa}$. The Epoxy resin has a compressive modulus of elasticity of $11.2 \mathrm{GPa}$, a tensile of $9.6 \mathrm{GPa}$, a compressive strength of $95 \mathrm{MPa}$, a shear strength of $19 \mathrm{MPa}$ and a tensile strength of $31 \mathrm{MPa}$.

Concerning cohesive interactions, we have opted for a tensile separation model, which determines the function of the opening between the two surfaces connected by this interaction [22-24]. It operates according to a linear elastic behaviour at the beginning, followed by the damage translated into openings that continue until the total degradation. This degradation represents the detachment of the strengthening [25]. Fig.4(C) and Eqns.1-4 can represent this behaviour model.

$$
\begin{aligned}
& T_{\max }=1.5 B_{w} \times f_{t} \\
& B_{w}=\sqrt{\left(2.25-\frac{b_{f}}{b_{c}}\right) /\left(1.25+\frac{b_{f}}{b_{c}}\right)} \\
& S_{0}=0.0195 B_{w}^{2} \times \sqrt{f_{t}} \\
& G_{f}=0.308 B_{w}^{2} \times \sqrt{f_{t}}
\end{aligned}
$$

$b_{f}:$ CFRP width.

$b_{c}$ : concrete widths.

$B_{w}$ : concrete width ratio on CFRP.

$G_{f}:$ total interracial rupture energy.

$S_{0}$ : effective separation at failure.

$T_{\max }:$ maximum interface strength.

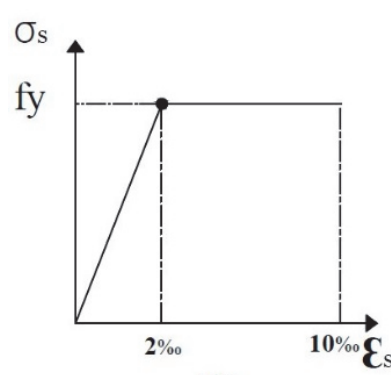

(A)

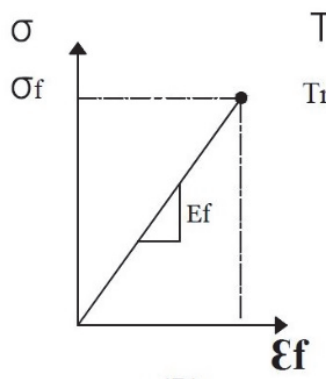

(B)

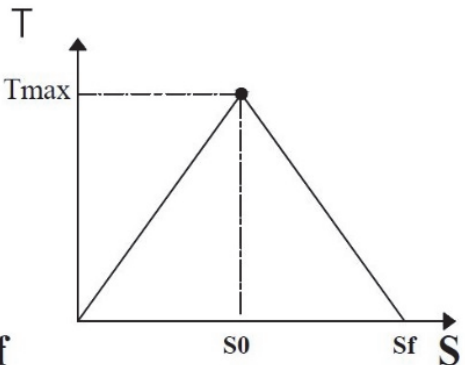

(C)

Figure 4: The behaviour laws. (A) Steel, (B) strengthening and (C) CFRP-Resin-Concert interface.

\section{NUMERICAL RESULTS AND DISCUSSIONS}

he results of the numerical studies are illustrated below in Figs. 5-9 and Tab. 3, 4, which shows the ultimate force, maximum deformation, materials behaviour, crack width evolution, failure mode and deformation ductility factor. This factor represents the ability of the materials to resist plastic deformation without significant stress reduction (Eq 5).

$$
\mu=\frac{\varepsilon_{u}}{\varepsilon_{y}}
$$


$\mu$ : deformation ductility factor.

$\varepsilon_{u}:$ ultimate deformation.

$\varepsilon_{\mathrm{y}}:$ elastic deformation.

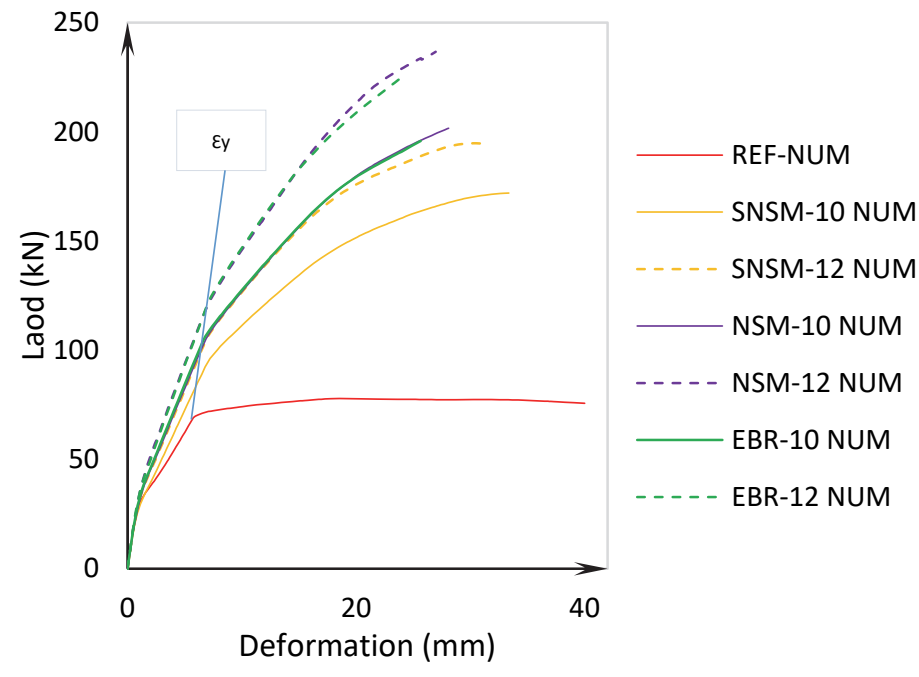

Figure 5: Deformation/force curves of the numerical study.

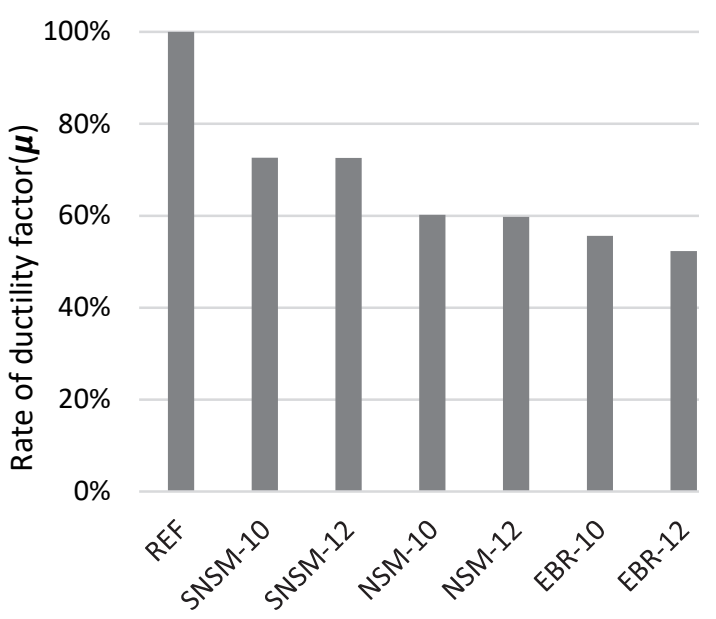

Figure 6: Comparison between the ductility factors of the modeled beams.

\begin{tabular}{|c|c|c|c|c|c|c|c|c|}
\hline ID & $\mathrm{N}^{\circ}$ & $\begin{array}{c}\mathrm{P}_{\mathrm{u}} \\
(\mathrm{kN})\end{array}$ & $\begin{array}{l}\text { Rate }(\%) \\
\mathrm{Pu} / \mathrm{REF}\end{array}$ & $\begin{array}{c}\mathcal{E}_{\mathrm{y}} \\
(\mathrm{mm})\end{array}$ & $\begin{array}{c}\mathcal{E}_{\mathrm{u}} \\
(\mathrm{mm})\end{array}$ & $\begin{array}{c}\boldsymbol{\mu} \\
\text { Ductility } \\
\text { factor }\end{array}$ & $\begin{array}{c}\text { Rate }(\%) \\
\text { Loss of ductility }\end{array}$ & Failure mode \\
\hline REF & 01 & 75.84 & $0 \%$ & 5.74 & 39.04 & 6.80 & $0.00 \%$ & Flexional failure \\
\hline SNSM-10 & 02 & 171.98 & $127 \%$ & 6.76 & 33.36 & 4.94 & $27.35 \%$ & Crushing of compressed concrete \\
\hline SNSM-12 & 03 & 194.57 & $157 \%$ & 6.36 & 31.37 & 4.94 & $27.39 \%$ & Crushing of compressed concrete \\
\hline NSM-10 & 04 & 201.71 & $166 \%$ & 6.86 & 28.09 & 4.09 & $39.77 \%$ & Concrete cover separation \\
\hline NSM-12 & 05 & 236.66 & $212 \%$ & 6.63 & 26.95 & 4.06 & $40.22 \%$ & Concrete cover separation \\
\hline EBR-10 & 06 & 195.48 & $158 \%$ & 6.78 & 25.65 & 3.78 & $44.36 \%$ & Debonding of the strengthening \\
\hline EBR-12 & 07 & 225.37 & $197 \%$ & 6.78 & 24.11 & 3.56 & $47.67 \%$ & Debonding of the strengthening \\
\hline
\end{tabular}

Table 3: Summary of the numerical results.

From Tab. 3, and Fig. 5, we can notice a significant improvement in the bending capacity for reinforced beams of about $127 \%$ for SNSM-10, 166\% for NSM-10 and 158\% for EBR-10 compared to the reference beam. This improvement can be explained by the increase in the internal lever arm of the reinforced sections. This increase varies from one technique to another depending on the position of the strengthening.

It was also found that the increase in the cross-section of the strengthened has a positive influence on the bending strength of the beams strengthened in different ways from one technique to another. Where there is a gain rate of $30 \%$ in resistance increase compared to the reference beam and between SNSM-10 and SNSM-12, up to 46\% between NSM-10 and NSM12 , and 39\%, between EBR-10 and EBR-12.

Through Fig. 6, we can notice that all reinforced beams have lost about $40 \%$ to $47 \%$ of their ductility compared to the reference beam due to the absence of a plastic bearing in the case of the CFRP. elsewhere, SNSM-strengthened beams have lost about $27.35 \%$ and $27.39 \%$ for SNSM-10 and SNSM-12 respectively. 


\begin{tabular}{|c|c|c|c|c|c|c|c|c|c|}
\hline \multirow[b]{2}{*}{ ID } & \multicolumn{3}{|c|}{ CONCRETE } & \multicolumn{3}{|c|}{ STEEL } & \multicolumn{3}{|c|}{ STRENGTHENING CFRP } \\
\hline & $\begin{array}{c}\mathcal{E}_{\mathrm{c}} \\
(\mathrm{mm} / \mathrm{m})\end{array}$ & $\begin{array}{c}\mathcal{E}_{\mathrm{cu}} \\
(\mathrm{mm} / \mathrm{m})\end{array}$ & $\begin{array}{l}\text { Rate } \\
(\%)\end{array}$ & $\begin{array}{c}\mathcal{E}_{\mathrm{s}} \\
(\mathrm{mm} / \mathrm{m})\end{array}$ & $\begin{array}{c}\mathcal{E}_{\mathrm{su}} \\
(\mathrm{mm} / \mathrm{m})\end{array}$ & Rate $(\%)$ & $\begin{array}{c}\mathcal{E}_{\mathrm{f}} \\
(\mathrm{mm} / \mathrm{m})\end{array}$ & $\begin{array}{c}\mathcal{E}_{\mathrm{fu}} \\
(\mathrm{mm} / \mathrm{m})\end{array}$ & Rate $(\%)$ \\
\hline REF NUM & $2.40 \%$ & $3.5 \%$ & $68.50 \%$ & $9.99 \%$ & $10 \%$ & $99.90 \%$ & - & - & - \\
\hline SNSM-10 NUM & $3.50 \%$ & $3.5 \%$ & $100 \%$ & $9.00 \%$ & $10 \%$ & $90.00 \%$ & $13.90 \%$ & $17 \%$ & $81.7 \%$ \\
\hline NSM-10 NUM & $2.77 \%$ & $3.5 \%$ & $79.14 \%$ & $7.77 \%$ & $10 \%$ & $77.70 \%$ & $10.00 \%$ & $17 \%$ & $58.82 \%$ \\
\hline EBR-10 NUM & $2.85 \%$ & $3.5 \%$ & 81.43 & $8.00 \%$ & $10 \%$ & $80.00 \%$ & $8.80 \%$ & $17 \%$ & $51.76 \%$ \\
\hline
\end{tabular}

Table 4: Summary of materials deformation.

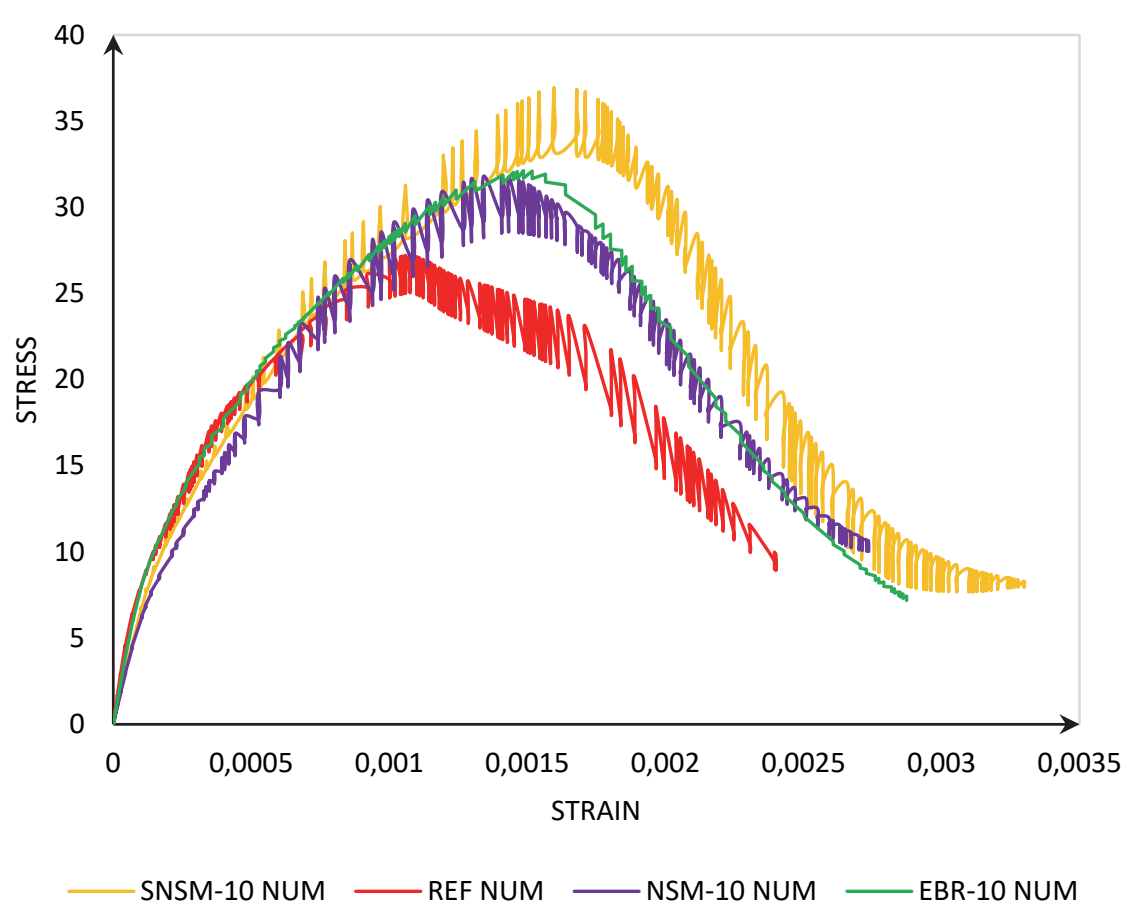

Figure 7: Concrete compressive behaviour.

A strengthening efficiency of $81.7 \%$ for the SNSM-10 NUM beam with full use of the concrete capacity in compression is shown in Tab. 4, and Fig. 7. These also show that the NSM-10 NUM and EBR-10 NUM beams had efficiency rates of 58\% and $51 \%$ respectively are explained by the brittle failure modes of the two beams.

Fig. 8 shows that the three techniques decreased the crack propagation compared to the reference beam for an average rate of $34 \%$.

Fig. 9(A) and Fig. 10(REF) show the strain distributions and the failure mode of the reference beam. This beam has undergone a typical bending failure, which manifested itself by cracks in the tensioned part, which starts to open from $8 \mathrm{kN}$ (Fig. 08) and continues to propagate until the tensioned reinforcements are plasticized.

The SNSM-10-NUM and SNSM-12-NUM beams that appeared in Fig. 9(B) and Fig. 10 (SNSM) has suffered a failure by crushing of the compressed concrete. The strengthening has allowed to reduce the first cracks where the first one appeared at $30 \mathrm{kN}$. 


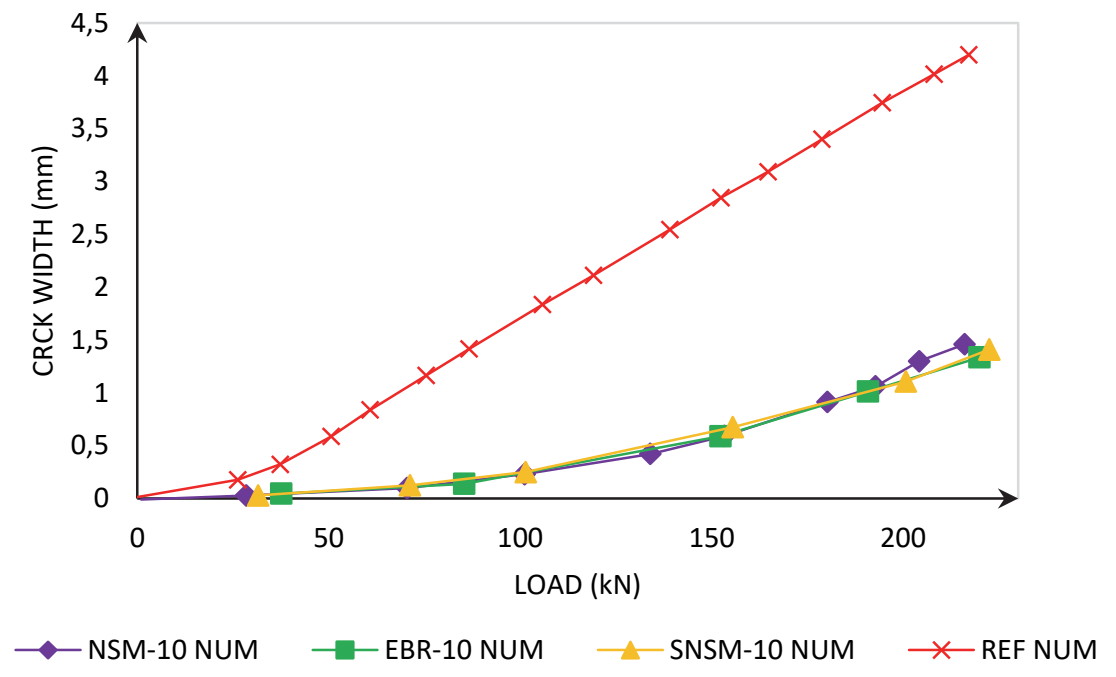

Figure 8: Load-crack width.

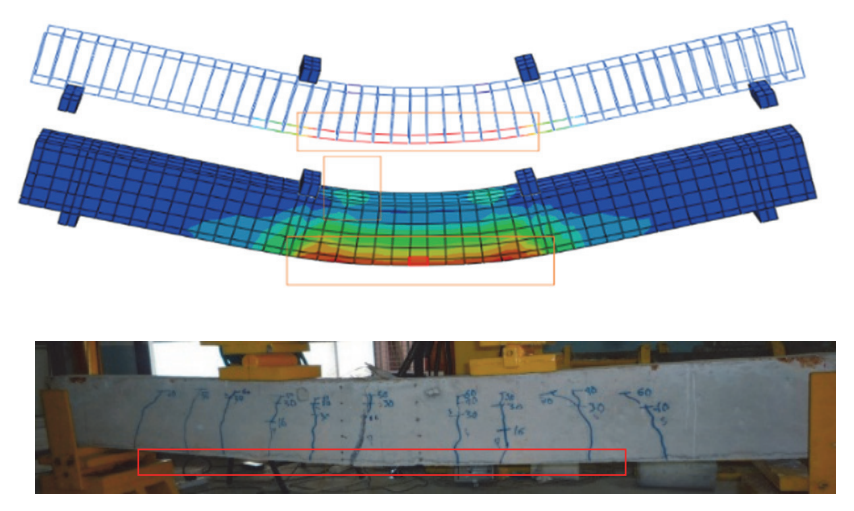

(A) REF Failure mode
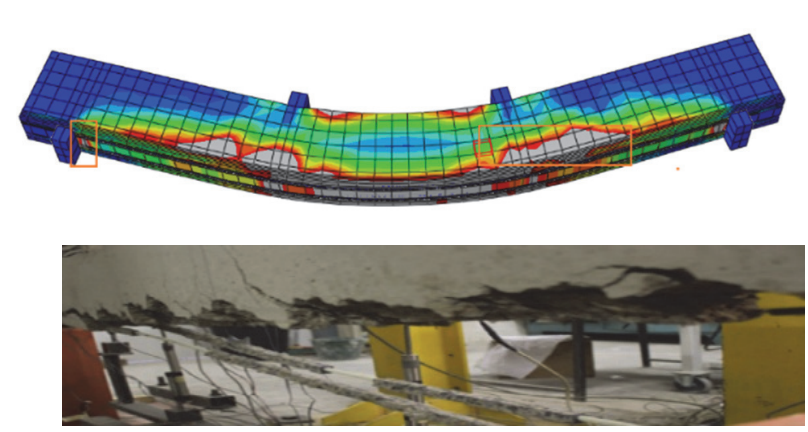

(C) NSM Failure mode
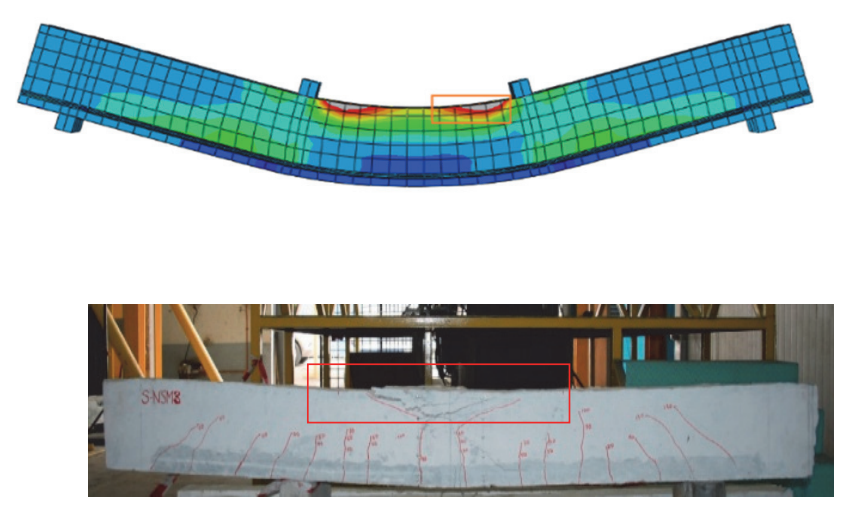

(B) SNSM Failure mode

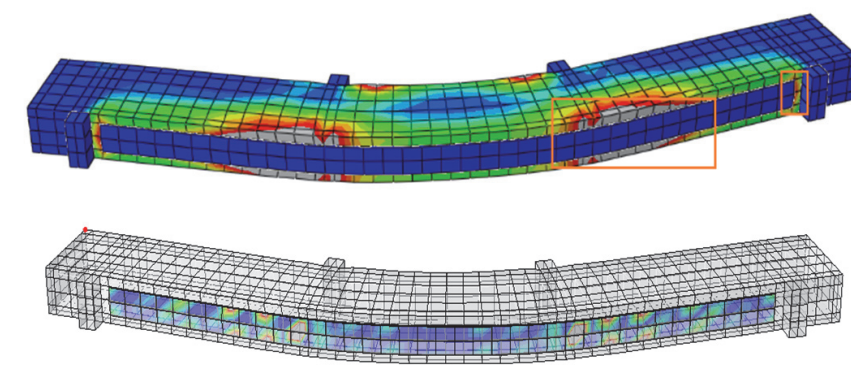

(D) EBR Failure mode

Figure 9: Comparison between the failure modes of numerical study and those found in the literature [18]. 

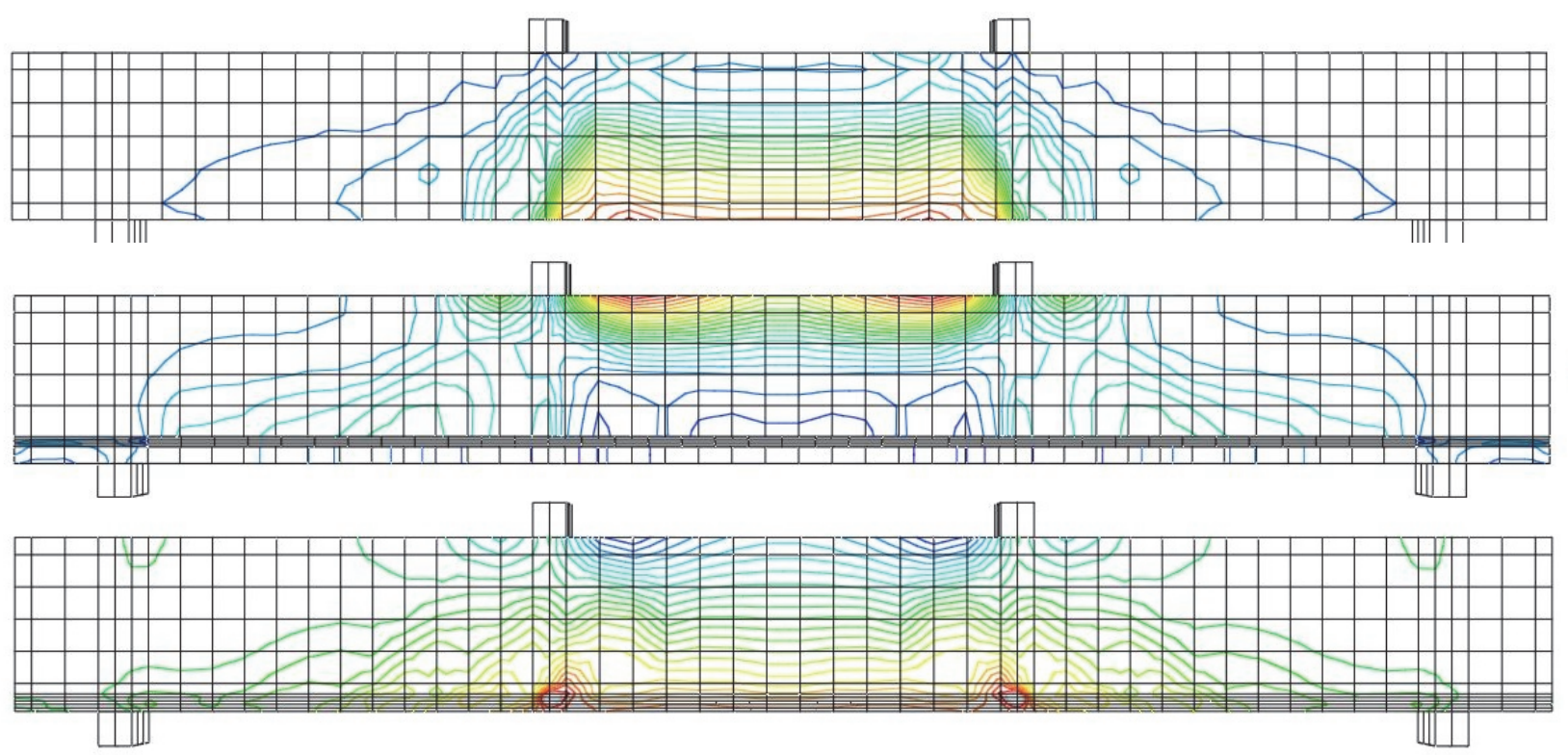

SNSM

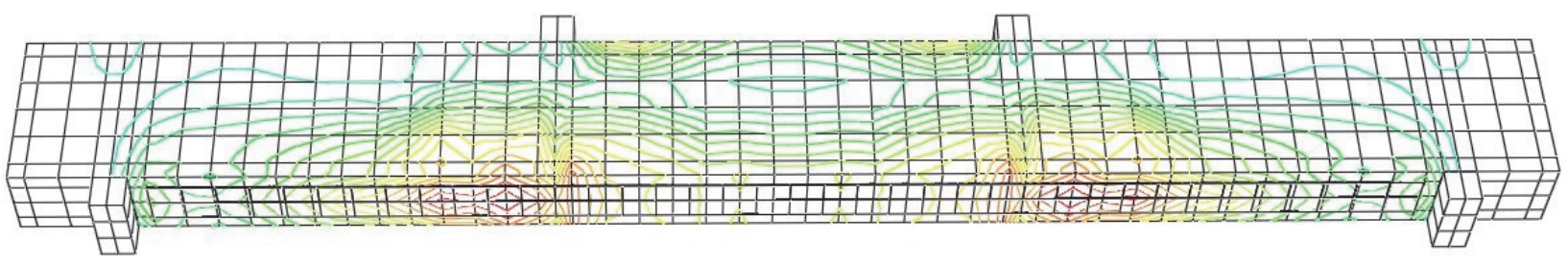

Figure 10: The strain distributions and the failure modes of numerical study.

A failure by concrete cover separation is shown in Fig. 9(C) and Fig.10(NSM), concerning NSM-10-NUM and NSM-12NUM beams. This failure manifested itself quickly and abruptly with a debonding of the lower part and exposure of the steel reinforcement. This is due to the good adhesion of the strengthening and the strength of the interface between the concrete and the strengthening. This perfect adhesion causes the creation of two rigid bodies that separate at the bottom of the strengthening under tension.

Fig. 9(D), and Fig. 10(EBR), show the failure mode of the beams EBR-10-NUM and EBR-12-NUM. This failure mode is manifested by the opening of a crack that begins to open in the concrete by stressing the FRP plate attached to it. The stresses created by the separation of the two ends of the crack cause horizontal cracking at the adhesive interface between the concrete and the strengthening. This cracking leads to the debonding of the strengthening. In fact, it is an intermediate crack induced by interfacial disbonding.

\section{ANALYTICAL STUDY}

1 his part is devoted to the development of an analytical model. The use of the stress diagram, the mechanical characteristics of the materials and the geometric characteristics of the sections is essential.

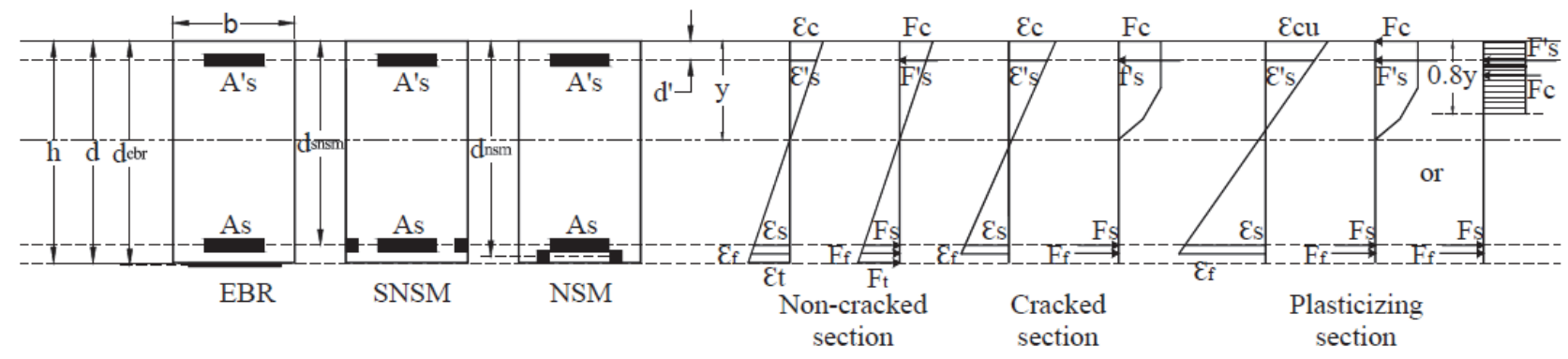

Figure 11: Reinforced beam sections. 
The behaviour of a reinforced concrete beam subjected to bending can be schematized as shown in Fig. 12, [26]. Where the deformation force curve can be divided into three parts:

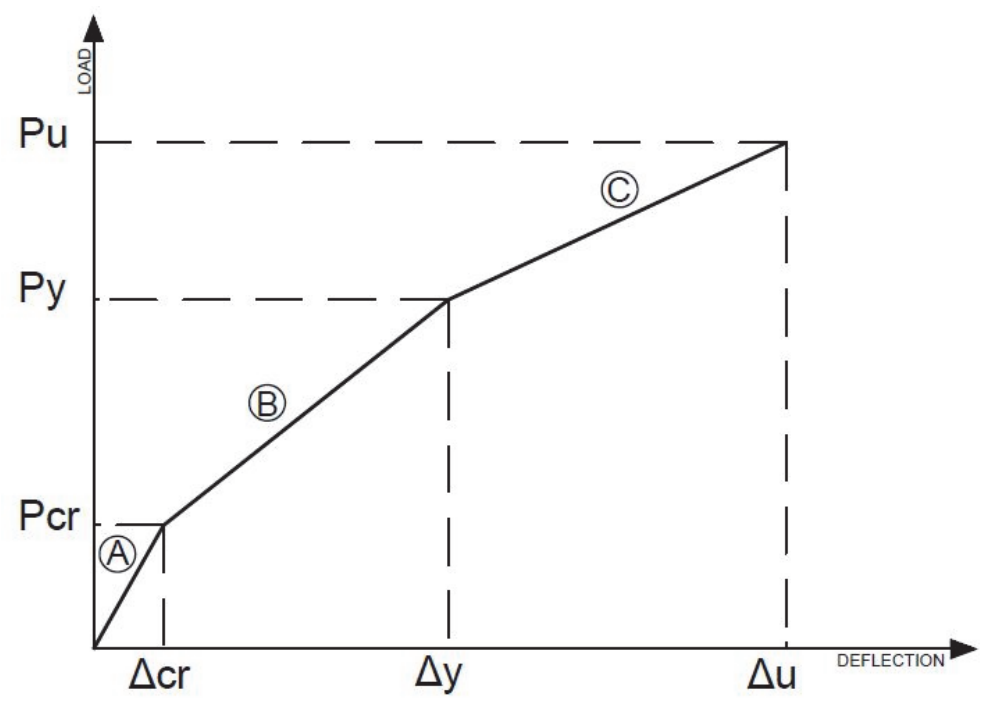

Figure 12: Typical force deformation curve of a reinforced concrete beam subjected to bending.

A- NON-CRACKED SECTION $0 \leq \mathrm{M}<\mathrm{MCR}$ :

The Force and the deformation $\left(P_{c r}, \Delta_{c r}\right)$ representing this phase were calculated from the neutral axis $y_{c r}$ according to the balance of the static moments of the section. The moments $M_{c r}$ and the inertia of the section $I_{c r}$ were calculated according to the transformed section method [26]:

$$
I_{c r}=\frac{b y_{c r}^{3}}{3}+\frac{b\left(b-y_{c r}\right)}{3}+(n-1) A_{s}\left(d-y_{c r}\right)^{2}+(n-1) A_{s}^{\prime}\left(y_{c r}-d^{\prime}\right)^{2}\left(n_{f}-1\right) A_{f}\left(d_{f}-y_{c r}\right)^{2}
$$

with, $A_{s}, A_{s}^{\prime}$ and $A_{f}$ the sections of the tensioned and compressed steels and the strengthening respectively, and $d_{f}$ is the ultimate height of the strengthening. Whose values in the equation change from one strengthening techniques to another according to the strengthening position.

$$
M_{c r}=\frac{I_{c r} \sigma_{t r}}{y_{c r}}
$$

with $\sigma_{t r}$ is the tensile stresses of the concert.

$$
\begin{aligned}
& P_{c r}=\frac{2 M_{c r}}{L_{a}} \\
& \Delta_{c u}=\frac{\left(P_{c r} / 2\right) L_{a}}{24 E_{c} I_{c r}}\left(3 L^{2}-4 L_{a}^{2}\right)
\end{aligned}
$$

$E_{c}$ is the concrete elasticity modulus; $L_{a}$ is the distance between the support and the applied force point and $L$ the span between supports. 


\section{B- CRACKED SECTION MCR $\leq \mathrm{M} \leq \mathrm{MY}$ :}

The cracked section is calculated by the same method as the non-cracked one. However, the tensioned part of the concrete is not considered in the calculation. Therefore, the neutral axis of section $y_{y}$ is calculated according to the balance of the static moments of the section, the moment $M_{y}$ and the section inertia $I_{y}$ are calculated by the following formulas [26]:

$$
\begin{aligned}
& I_{y}^{\prime}=\frac{b y_{y}^{3}}{3}+(n) A_{s}\left(d-y_{y}\right)^{2}+(n) A_{s}^{\prime}\left(y_{y}-d^{\prime}\right)^{2}\left(n_{f}\right) A_{f}\left(d_{f}-y_{y}\right)^{2} \\
& I_{y}=I_{y}^{\prime} /\left[1-\left(1-\frac{I_{y}^{\prime}}{I_{c r}}\right)\left(\frac{M_{c r}}{M}\right)\right] \\
& M_{y}=\frac{I_{y} \sigma_{f}}{n_{f}\left(d_{f}-y_{y}\right)}
\end{aligned}
$$

with $\sigma_{f}$ representing the tensile stresses of the strengthening.

$$
\begin{aligned}
& P_{y}=\frac{2 M_{y}}{L_{a}} \\
& \Delta_{y}=\frac{\left(P_{y} / 2\right) L_{a}}{24 E_{c} I_{y}}\left(3 L^{2}-4 L_{a}^{2}\right)
\end{aligned}
$$

\section{C- Plasticizing SeCtion $\mathrm{MY}<\mathrm{M} \leq \mathrm{MU}$ :}

The ultimate moment $M_{u}$, that represents the failure point of the beam, is calculated using the successive test method. This method allows determining the depth of the neutral axis $y_{u}$ depending on the deformation compatibility of the concrete. Where the deformation of the concrete is taken at $\mathcal{E}_{c u}=3.5 \%$, while $\mathcal{E}_{s}$ and $\mathcal{E}_{s}^{\prime}$ deformation of steel and $\mathcal{E}_{f}$ deformation of the composite material are expressed by the following equations [27, 28]:

$$
\begin{aligned}
& \varepsilon_{s}=\left(\frac{d-y_{u}}{y_{u}}\right) \varepsilon_{c u} \\
& \varepsilon_{s}^{\prime}=\left(\frac{y_{u}-d^{\prime}}{y_{u}}\right) \varepsilon_{c u} \\
& \varepsilon_{f}=\left(\frac{d_{f}-y_{u}}{y_{u}}\right) \varepsilon_{c u}
\end{aligned}
$$

So, the formula of the moment can be expressed as follows from the balance of internal forces $F_{s}$, $F_{s}^{\prime}$ of steel and $F_{f}$ for reinforcements: 


$$
\begin{aligned}
& M_{u}=F_{s}\left(d-0.4 y_{u}\right)+F_{s}^{\prime}\left(0.4 y_{u}-d^{\prime}\right)+F_{f}\left(d_{f}-0.4 y_{u}\right) \\
& P_{u}=\frac{2 M_{u}}{L_{a}}
\end{aligned}
$$

while, $\Delta_{u}$ is calculated from the curvature $\varphi$ :

$$
\begin{aligned}
& \varphi_{u}=\frac{\varepsilon_{c u}}{y_{u}} \\
& \varphi_{s}=\frac{\varepsilon_{s}}{\left(d-y_{u}\right)} \\
& \varphi=\varphi_{s}+\frac{M-M_{y}}{M_{u}-M}\left(\varphi_{u}-\varphi_{s}\right) \\
& I_{u}=\frac{M}{E_{c} \varphi} \\
& \Delta_{u}=\frac{\left(P_{u} / 2\right) L_{a}}{24 E_{c} I_{u}}\left(3 L^{2}-4 L_{a}^{2}\right)
\end{aligned}
$$

\section{ANALYTICAL RESULTS, DISCUSSIONS AND VALIDATION}

1

he results of the analytical part, presented in Fig. 13(B), show a very good agreement between the numerical and analytical study for the reference RC beam and the SNSM strengthened beam. However, an overestimation is found for the EBR beam and an underestimation for the NSM beam. This is due to the hypothesis of the perfect adhesion between the concrete and the strengthening.

In order to validate the numerical study, the results obtained, in particular the force-displacement curves, were compared with the analytical results and those from the experimental study conducted by Hosen et al [18]. Where the beams tested in the last one is identical to the beams modelled.

Fig.13(A) depicts the comparison between the force-displacement curves of the beams from the numerical and experimental study, where a good consistency is perceived. This consistency is translated into ultimate load accuracy rates of $95 \%$ and 96\% for the REF and SNSM-10 beams, respectively. Furthermore, Fig.13(B) shows the comparison between the forcedisplacement curves of the beams from the numerical and analytical study. Where the accuracy of the ultimate load of REF and EBR-10 beams is $97 \%$ with $93 \%$ and $80 \%$ for SNSM-10 and NSM-10 beams, respectively.

Tab. 5 shows the adequacy of the results compared to previous studies. In particular, those related to the failure modes where $85 \%$ of the RC beams submitted to a ductile failure by crushing the compressed part of the concrete, which confirms our results. On the other hand, other beams reinforced by higher quantities of FRP had a failure by deboning of the concrete covering justified by the considerable increase in the rigidity of the lower part of the beams. 


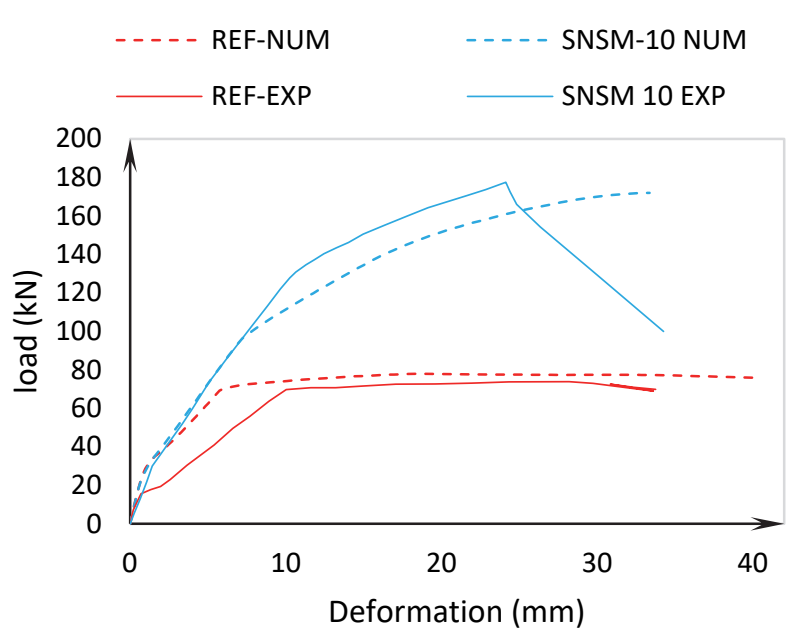

(A) Comparison between the experimental and numerical study

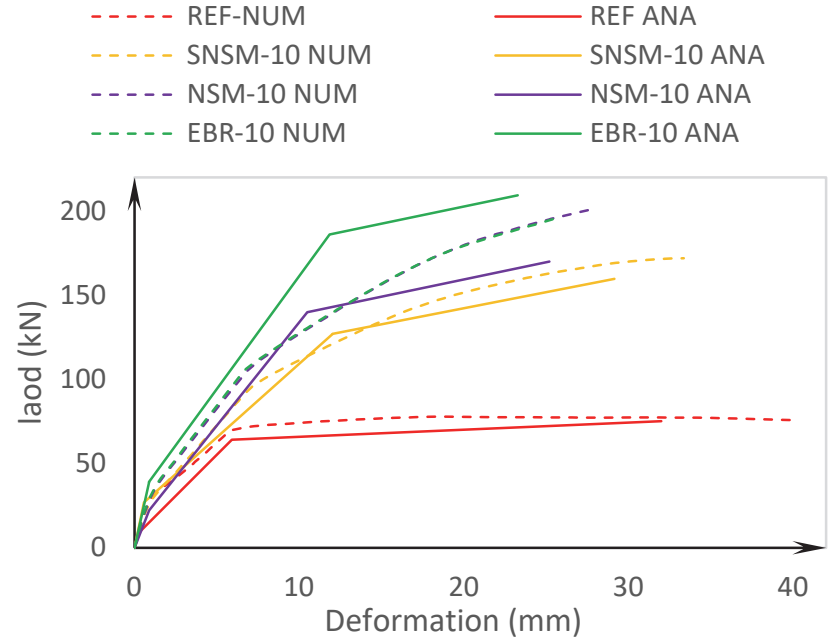

(B) Comparison between analytical and numerical study

Figure 13: Comparison between load-defection curves.

\begin{tabular}{|c|c|c|c|c|c|c|c|c|c|}
\hline \multirow{2}{*}{$\begin{array}{l}\text { Other } \\
\text { studies }\end{array}$} & \multirow[b]{2}{*}{ Designation } & \multirow{2}{*}{$\begin{array}{c}\mathrm{b} \\
(\mathrm{mm})\end{array}$} & \multirow{2}{*}{$\begin{array}{c}1 \\
(\mathrm{~mm})\end{array}$} & \multirow{2}{*}{$\begin{array}{c}\mathrm{h} \\
(\mathrm{mm})\end{array}$} & \multicolumn{2}{|c|}{ Main longitudinal steel } & \multirow{2}{*}{$\begin{array}{c}\mathrm{Pu} \\
(\mathrm{kN})\end{array}$} & \multirow{2}{*}{$\begin{array}{l}\delta \max \\
(\mathrm{mm})\end{array}$} & \multirow[b]{2}{*}{ Failure mode } \\
\hline & & & & & $\begin{array}{c}\text { Top } \\
\left(\mathrm{mm}^{2}\right)\end{array}$ & $\begin{array}{l}\text { Bottom } \\
\left(\mathrm{mm}^{2}\right)\end{array}$ & & & \\
\hline $\begin{array}{c}\text { Md. Akter } \\
\text { hosen et al } \\
{[19]}\end{array}$ & $\begin{array}{l}\mathrm{Cb} \\
\mathrm{S} 2 \mathrm{~h} \\
\mathrm{~S} 2 \mathrm{v} \\
\mathrm{S} 3 \mathrm{~h} \\
\mathrm{~S} 3 \mathrm{v} \\
\mathrm{S} 4 \mathrm{~h} \\
\mathrm{~S} 4 \mathrm{v}\end{array}$ & 125 & 2300 & 250 & $\begin{array}{l}157 \\
157 \\
157 \\
157 \\
157 \\
157 \\
157\end{array}$ & $\begin{array}{l}226.08 \\
226.08 \\
226.08 \\
226.08 \\
226.08 \\
226.08 \\
226.08\end{array}$ & $\begin{array}{c}68 \\
153 \\
138 \\
154 \\
160 \\
156 \\
168\end{array}$ & $\begin{array}{l}35.33 \\
47.60 \\
46.85 \\
48.23 \\
48.06 \\
27.03 \\
42.63\end{array}$ & $\begin{array}{c}\text { Flexural failure } \\
\text { Flexural failure } \\
\text { Flexural failure } \\
\text { Flexural failure } \\
\text { Flexural failure } \\
\text { End cover separation } \\
\text { Flexural failure }\end{array}$ \\
\hline $\begin{array}{c}\text { Md. Akter } \\
\text { hosen et al } \\
\quad[18]\end{array}$ & $\begin{array}{c}\text { CB } \\
\text { SNS8 } \\
\text { SNS10 } \\
\text { SNS12 } \\
\text { SNC8 } \\
\text { SNC10 } \\
\text { SNC12 }\end{array}$ & 125 & 2300 & 250 & $\begin{array}{l}157 \\
157 \\
157 \\
157 \\
157 \\
157 \\
157\end{array}$ & $\begin{array}{l}226.08 \\
226.08 \\
226.08 \\
226.08 \\
226.08 \\
226.08 \\
226.08\end{array}$ & $\begin{array}{l}70 \\
140 \\
180 \\
180 \\
110 \\
130 \\
140\end{array}$ & $\begin{array}{l}35 \\
25 \\
28 \\
18 \\
40 \\
20 \\
18\end{array}$ & $\begin{array}{c}\text { Flexural failure } \\
\text { Flexural failure } \\
\text { Flexural failure } \\
\text { End cover separation } \\
\text { Flexural failure } \\
\text { Flexural failure } \\
\text { End cover separation }\end{array}$ \\
\hline $\begin{array}{l}\text { A.A. Shukri } \\
\text { et al [29] }\end{array}$ & $\begin{array}{c}\text { CB } \\
\text { SNC8 } \\
\text { SNC10 } \\
\text { SNC12 } \\
\text { PSNC10 } \\
\text { PSNC12 }\end{array}$ & 125 & 2300 & 250 & $\begin{array}{l}157 \\
157 \\
157 \\
157 \\
157 \\
157 \\
157\end{array}$ & $\begin{array}{l}226.08 \\
226.08 \\
226.08 \\
226.08 \\
226.08 \\
226.08 \\
226.08\end{array}$ & $\begin{array}{l}74.37 \\
142.03 \\
176.78 \\
173.02 \\
141.54 \\
171.13 \\
169.41\end{array}$ & $\begin{array}{l}33.61 \\
22.27 \\
24.03 \\
16.89 \\
25.99 \\
20.95 \\
13.86\end{array}$ & $\begin{array}{c}\text { Flexural failure } \\
\text { Flexural failure } \\
\text { Flexural failure } \\
\text { Flexural failure } \\
\text { Flexural failure } \\
\text { Flexural failure } \\
\text { End cover separation }\end{array}$ \\
\hline $\begin{array}{l}\text { Abdallah, M } \\
\text { et al [30] }\end{array}$ & $\begin{array}{l}\mathrm{CB} \\
\mathrm{BC} 1 \\
\mathrm{BC} 2 \\
\mathrm{BC} 3 \\
\mathrm{BC} 4 \\
\mathrm{BC} 5\end{array}$ & 150 & 3000 & 280 & $\begin{array}{l}56.5 \\
56.5 \\
56.5 \\
56.5 \\
56.5 \\
56.5\end{array}$ & $\begin{array}{l}226.08 \\
226.08 \\
226.08 \\
226.08 \\
226.08 \\
226.08\end{array}$ & $\begin{array}{c}72.8 \\
116.0 \\
106.4 \\
106.0 \\
94.1 \\
102.7\end{array}$ & $\begin{array}{l}59.3 \\
50.4 \\
22.9 \\
38.2 \\
16.2 \\
40.4\end{array}$ & $\begin{array}{l}\text { Flexural failure } \\
\text { Flexural failure } \\
\text { Cover separation } \\
\text { Flexural failure } \\
\text { Flexural failure } \\
\text { Flexural failure }\end{array}$ \\
\hline
\end{tabular}

Table. 5: Summary of similar studies. 


\section{CONCLUSION}

7 his study aims to establish an analytical model and numerical simulation to compare the three reinforcement techniques: SNSM, NSM and EBR. Where the bending capacity, ductility, failure modes of the beams and the impact of the strengthening amount were verified. With the results obtained, it can be noticed that:

- The numerical and analytical models used allow predicting the behaviour of strengthened reinforced concrete beams according to the three techniques with $95 \%$ of pressure and consistency between the numerical, experimental, and analytical results.

- The numerical modelling allows predicting the failure modes of the beams modeled in comparison with the literature.

- A significant increase in flexural capacity was observed for all three strengthening techniques. However, a considerable increase in rigidity caused brittle failures modes for NSM and EBR in contrast to SNSM, where ductility is better preserved.

- The results relating to the deformations and the materials lengthening allow to conclude that beams reinforced according to the SNSM technique have a better strengthening efficiency of about $81.7 \%$.

- The SNSM technique made it possible to avoid the failure mode by debonding and concrete cover separation causing a better failure mode by crushing of compressive concrete.

- The increase in the amount of strengthening has a positive influence on the flexural capacity of the reinforced beams according to the three techniques.

\section{REFERENCES}

[1] Khalifa, A.M. (1999). Shear Performance of Reinforced concrete beams strengthened with advanced composites, PhD thesis, Department of Structural Engineering, University of Alexandria, Egypt.

[2] Oehlers, D., Seracino, R. (2004). Design of FRP and Steel Plated RC Structures: Retrofitting Beams and Slabs for Strength, Stiffness and Ductility.

[3] Sumathi, A., Vignesh, S.A. (2017). Study on behavior of RCC beams with externally bonded FRP members in flexure, Adv. Concr. Constr., 5, pp. 625-638, DOI: 10.12989/acc.2017.5.6.625.

[4] Rahimi, H., Hutchinson, A. (2001). Concrete beams strengthened with externally bonded FRP plates, J. Compos. Constr., 5(1), pp. 44-57, DOI: 10.1061/(ASCE)1090-0268(2001)5:1(44).

[5] Oehlers, D.J., Rashid, R., Seracino, R. (2008). IC debonding resistance of groups of FRP NSM strips in reinforced concrete beams, Constr. Build. Mater., 22(7), pp. 1305-1600, DOI: 10.1016/j.conbuildmat.2007.03.021.

[6] Smith, S.T., Teng, J.G. (2002). FRP-strengthened RC beams. II: Assessment of debonding strength models, Eng. Struct., 24(4), pp. 385-527, DOI: 10.1016/S0141-0296(01)00106-7.

[7] Yao, J., Teng, J.G. (2007). Plate end debonding in FRP-plated RC beams-I: Experiments, Eng. Struct.. (29(10), pp. 2419-280, DOI: $10.1016 /$ j.engstruct.2006.11.022.

[8] Nanni, A. (2000). Frp Reinforcement for Bridge Structures, Proceedings, Strucural Eng. Conf. "FRP Reinf. Bridg. Struct., 5, DOI: 10.1016/j.clinthera.2013.03.019.

[9] Barros, J.A.O., Fortes, A.S. (2005). Flexural strengthening of concrete beams with CFRP laminates bonded into slits, Cem. Concr. Compos., 27, pp. 471-480, DOI: 10.1016/j.cemconcomp.2004.07.004.

[10] Barros, J., Kotynia, R. (2008). Possibilities and challenges of NSM for the flexural strengthening of RC structures. Proceedings of the 4th International Conference on FRP Composites in Civil Engineering, CICE 2008.

[11] Bilotta, A., Ceroni, F., Nigro, E., Pecce, M. (2015). Efficiency of CFRP NSM strips and EBR plates for flexural strengthening of RC beams and loading pattern influence, Compos. Struct., 124, pp. 163-175, DOI: $10.1016 /$ j.compstruct.2014.12.046.

[12] Sharaky, I.A., Torres, L., Comas, J., Barris, C. (2014). Flexural response of reinforced concrete (RC) beams strengthened with near surface mounted (NSM) fibre reinforced polymer (FRP) bars, Compos. Struct., 109, pp. 8-22, DOI: $10.1016 /$ j.compstruct.2013.10.051.

[13] Sharaky, I.A., Torres, L., Sallam, H.E.M. (2015). Experimental and analytical investigation into the flexural performance of RC beams with partially and fully bonded NSM FRP bars/strips, Compos. Struct., 122, pp. 113-126,

DOI: $10.1016 /$ j.compstruct.2014.11.057. 
[14] Hosen, M.A., Jumaat, M.Z., Islam, A.B.M.S., Kamruzzaman, M., Huda, M.N., Soeb, M.R. (2015). Eliminating concrete cover separation of NSM strengthened beams by CFRP end anchorage, Struct. Eng. Mech., 56(6), DOI: 10.12989/sem.2015.56.6.899.

[15] Fathuldeen, S.W., Qissab, M.A. (2019). Behavior of RC beams strengthened with NSM CFRP strips under flexural repeated loading, Struct. Eng. Mech., 70(1), pp.67-80, DOI: 10.12989/sem.2019.70.1.067.

[16] Ramezanpoura, M., Morshed, R., Eslamib, A. (2018). Experimental investigation on optimal shear strengthening of RC beams using NSM GFRP bars, Struct. Eng. Mech., 67(1), pp. 45-52, DOI: 10.12989/sem.2018.67.1.045.

[17] Al-Mahmoud, F., Castel, A., François, R., Tourneur, C. (2009). Strengthening of RC members with near-surface mounted CFRP rods, Compos. Struct., 91(2), pp. 131-236, DOI: 10.1016/j.compstruct.2009.04.040.

[18] Hosen, M.A., Jumaat, M.Z., Islam, A.B.M.S. (2015). Side Near Surface Mounted (SNSM) technique for flexural enhancement of RC beams, Mater. Des., 83, pp. 587-597, DOI: 10.1016/j.matdes.2015.06.035.

[19] Hosen, M.A., Jumaat, M.Z., Alengaram, U.J., Ramli Sulong, N.H. (2018). CFRP strips for enhancing flexural performance of RC beams by SNSM strengthening technique, Constr. Build. Mater., 165, pp. 28-44, DOI: $10.1016 /$ j.conbuildmat.2017.12.052.

[20] Roja, S.Y., Magudeaswaran, P., Dharma, S.M., Eswaramoorthi, D.P. (2016). Analytical Study on Flexural Behaviour of Concrete Beams Reinforced With Steel Rebars By Abaqus, Int. J. Res. Innov. Eng. Technol., 57(3), pp. 1693-1712, DOI: $10.1016 /$ j.aej.2017.03.035.

[21] Senthil, K., Gupta, A., Singh, S.P. (2018). Computation of stress-deformation of deep beam with openings using finite element method, Adv. Concr. Constr., 6(3), pp.245-268, DOI: 10.12989/acc.2018.6.3.245.

[22] Obaidat, Y., Dahlblom, O., Heyden, S. (2010).Nonlinear FE modelling of shear behaviour in RC beam retrofitted with CFRP. Computational Modelling of Concrete Structures., pp 47-56, DOI: 10.1201/b10546-80.

[23] Obaidat, Y.T., Heyden, S., Dahlblom, O. (2010). FEM study on the effect of CFRP stiffness and width on retrofitted reinforced concrete beam behaviour, Structural Retrofitting of Reinforced Concrete Beams Using Carbon Fibre Reinforced Polymer., pp 59-78.

[24] Obaidat, Y.T., Heyden, S., Dahlblom, O. (2010). The effect of CFRP and CFRP/concrete interface models when modelling retrofitted RC beams with FEM, Compos. Struct., 92(6), pp. 1283-1544, DOI: $10.1016 /$ j.compstruct.2009.11.008.

[25] Camanho, P., Davila, C.G. (2002). Mixed-Mode Decohesion Finite Elements in for the Simulation Composite of Delamination Materials, Nasa., 37(16), pp. 1415-1438, DOI: 10.1177/002199803034505.

[26] Said, H. (2010). Deflection prediction for FRP-strengthened concrete beams, J. Compos. Constr., 14(2), pp. 244-248, DOI: $10.1061 /($ ASCE)CC.1943-5614.0000069.

[27] ACI 440.2R-08. (2008). Guide for the design and construction of externally bonded FRP systems for strengthening existing structures.

[28] Boukhezar, M., Samai, M.L., Mesbah, H.A., Houari, H. (2013). Flexural behaviour of reinforced low-strength concrete beams strengthened with CFRP plates, Struct. Eng. Mech., 47(6), pp. 819-838, DOI: 10.12989/sem.2013.47.6.819.

[29] Shukri, A.A., Hosen, M.A., Muhamad, R., Jumaat, M.Z. (2016). Behaviour of precracked RC beams strengthened using the side-NSM technique, Constr. Build. Mater., 123(1), pp. 617-626, DOI: 10.1016/j.conbuildmat.2016.07.066.

[30] Abdallah, M., Al Mahmoud, F., Boissière, R., Khelil, A., Mercier, J. (2020). Experimental study on strengthening of RC beams with Side Near Surface Mounted technique-CFRP bars, Compos. Struct., 234, 111716, DOI: $10.1016 /$ j.compstruct.2019.111716.

[31] Stoner, J.G. (2015). Finite Element Modelling of GFRP Reinforced Concrete Beams, Master's Thesis, University of waterloo, Waterloo, Canada.

[32] Jahami, A., Temsah, Y., Khatib, J. (2019). The efficiency of using CFRP as a strengthening technique for reinforced concrete beams subjected to blast loading, Int. J. Adv. Struct. Eng., 11(4), pp. 411-20,

DOI: $10.1007 /$ s40091-019-00242-w. 